Research paper

\title{
Mineral and textural transformations in aluminium-rich clays during ceramic firing
}

\author{
Elisa Laita*, Blanca Bauluz \\ IUCA-Department of Earth Sciences, Faculty of Sciences, Pedro Cerbuna 12, Universidad de Zaragoza, Spain
}

\section{A R T I C L E I N F O}

\section{Keywords:}

Aluminium-rich clays

Ceramics

Clays

Electron microscopy

Mineral transformations

Mullite

\begin{abstract}
A B S T R A C T
The aim of this study has been to analyse the mineralogical and textural transformations of a set of aluminiumrich shales of interest for refractory and ceramic uses, fired from $800{ }^{\circ} \mathrm{C}$ to $1300{ }^{\circ} \mathrm{C}$. To that end, raw and fired samples were analysed by X-ray diffraction, transmitted light microscopy, field emission scanning electron microscopy, and transmission electron microscopy. Raw samples comprise variable proportions of illite, pyrophyllite, orthoclase, quartz, kaolinite, mixed-layer I-Sm, and organic matter. At temperatures below $800{ }^{\circ} \mathrm{C}$, kaolinite, mixed-layer I-Sm, and organic matter are destabilized, indicating that they are the least stable phases in the firing process. Illite, pyrophyllite, and orthoclase remain until $1000{ }^{\circ} \mathrm{C}$ and show a broader stability field during firing than in natural environments. Quartz persists throughout the entire firing process, although it is partly replaced by vitreous phase. Hematite crystallizes at $900{ }^{\circ} \mathrm{C}$. Vitrification begins at $1000{ }^{\circ} \mathrm{C}$, marking the first significant textural change. From $1000{ }^{\circ} \mathrm{C}$ mullite starts to crystallize from the $\mathrm{Si}$ - and Al-rich vitreous phase. The mullite composition is not stoichiometric and probably as temperature increases $\mathrm{Si}$ is partially replaced by $\mathrm{Al}, \mathrm{Fe}$ and $\mathrm{Ti}$ in the structure. Nevertheless, with the increase of the firing temperature, the mullite composition is closer to the theoretical composition and also to that of natural mullites. Furthermore its crystal thickness increases with temperature up to $70 \mathrm{~nm}$.
\end{abstract}

\section{Introduction}

Nowadays, aluminium-rich clays with kaolinite and pyrophyllite are of great industrial interest because these clays are the most important raw material in stoneware and high-quality ceramic floor tile manufacturing as well as in refractory ceramics. Due to this interest, knowledge of the phases and mineral transformations taking place during firing is useful in order to determine the most appropriate conditions for the dynamic of the firing and vitrification temperatures. In order to understand the ceramic process it is important to deepen in the knowledge of textural changes, mineral reactions and variations in compositions of the phases with the increase of the temperature both at micron and nano scale.

Previous papers (Cultrone et al., 2001; Wattanasiriwech et al., 2009) have described mineralogical and textural changes in illite and smectite rich-clays with variable proportions of carbonates during firing. In general, these works show an increase of the vitrification process and crystallization of new phases as mullite, and/or $\mathrm{Ca}, \mathrm{Mg}$ silicates with temperature. As Maggetti (1982) indicates, the mineral transformations that occur when a clay-rich sediment is fired in a process with high-T and low-P are mainly influenced by the mineralogical composition of the raw clay-rich material, its granulometry, the firing temperature as well as the kiln atmosphere conditions.

To conduct the study, a set of aluminium-rich shale samples from the Iberian Range (in NE Spain) were selected. Samples from this location had been previously studied by Bauluz and Subías (2010) in order to determine their mineral composition and genesis. These shales are characterized by significant amounts of pyrophyllite and kaolinite, organic matter, and the absence of carbonates. The shale mineralogy consists of quartz, pyrophyllite, illite, micas, mixed-layer illite/smectite (I-Sm), chlorite, and kaolinite (Bauluz and Subías, 2010).

The aim of this work was to combine X-ray diffraction (XRD), optical and field emission scanning electron microscopy (FESEM), and transmission electron microscopy (TEM) in order to describe and determine the mineralogical and textural changes of residual and newly formed phases in samples fired at different temperatures. The chemistry of transformed and/or neoformed phases was also given particular consideration.

\section{Geological setting}

The samples analysed in this study were taken from a shale outcrop

\footnotetext{
* Corresponding author

E-mail address: 629846@unizar.es (E. Laita).
} 
in the western branch of the Iberian Range at the following geographical coordinates: $\mathrm{N} 40^{\circ} 35^{\prime} 24.7^{\prime \prime}$ W01 $46^{\prime} 49.0^{\prime \prime}$ elevation $1365 \mathrm{~m}$ (sample BSCH-7B), N40 $28^{\prime} 26.2^{\prime \prime}$ W01 $38^{\prime} 47.1^{\prime \prime}$ elevation $1571 \mathrm{~m}$ (sample CHECA-3B), and N40 $27^{\prime} 44.2^{\prime \prime}$ W01 ${ }^{\circ} 37^{\prime} 58.1^{\prime \prime}$ elevation $1447 \mathrm{~m}$ (sample CHECA-5B). Samples belong to the Pizarras de Checa Formation, Upper Aeronian to Lower Ludfordian (Gutiérrez-Marco and Storch, 1998). The coexistence of pyrophyllite, mixed-layer I-Sm, illite, kaolinite, and chlorite is due to the combination of sedimentary, lowgrade metamorphic- and low-temperature hydrothermal processes (Bauluz and Subías, 2010). According to these authors, three stages are identified: 1) Black shale deposition and subsequent diagenetic processes that produced the coexistence of quartz, illite, kaolinite, and organic matter. 2) Intrusion of andesite sills producing hydrothermal alteration and the crystallization of pyrophyllite, illite, mixed-layer ISm, and jarosite. 3) Shales, sill folding, and penetrative foliation leading to the recrystallization of illite and paragonite.

\section{Materials and methods}

\subsection{Samples and firing process}

The selection of the samples for this study, labelled as CHECA-3B, CHECA-5B, and BSCH-7B, was made on the basis of their mineralogy. The three samples contain pyrophyllite, kaolinite and illite in different proportions. Therefore they are appropriate to analyse de mineralogical changes of these clays with firing.

Cylinders ( $4.5 \mathrm{~cm}$ in diameter and $2.5 \mathrm{~cm}$ high) were manufactured from the raw clays by pressing the under $400 \mu \mathrm{m}$ fraction of the milled samples and then fired in a Tecno-piro PR4T oven. The firing temperatures were $800{ }^{\circ} \mathrm{C}, 900{ }^{\circ} \mathrm{C}, 1000{ }^{\circ} \mathrm{C}, 1100{ }^{\circ} \mathrm{C}, 1200{ }^{\circ} \mathrm{C}$, and $1300{ }^{\circ} \mathrm{C}$ under oxidizing conditions, with temperature steps of $200{ }^{\circ} \mathrm{C} / \mathrm{h}$, and the maximum temperature maintained for $2 \mathrm{~h}$.

\section{2. $X$-ray diffraction}

Mineralogical analyses were performed by X-ray diffraction (XRD) on the three natural samples and those fired at different temperatures. To obtain the diffraction patterns, a Philips 1710 diffractometer was used with $40 \mathrm{kV}$ voltage, $30 \mathrm{~mA}$ current, CuKa, automatic slit, and a graphite monochromator. XRD patterns were obtained from the $3-80^{\circ} 2 \theta$ interval with a goniometer velocity of $0.03^{\circ} 2 \theta / \mathrm{s}$ and an integration time of $0.5 \mathrm{~s}$. The record was made with the Software XPowder (Martín, 2007).

Once the minerals present in the samples were determined, the values of the reference intensity ratios (RIR) of each mineral phase were established, with corundum (cor). The RIR value is the relation between the intensity of the peak of interest and that of the standard peak in an XRD pattern. This value allows us to subsequently quantify the different minerals in the samples. To obtain the RIR value, pure standards were selected for hematite (NENO90 from Tierga, Spain), illite (Source Clays Repository from Silver Hill, Mont), kaolinite (Source Clays Repository from Warren County, Georgia, USA), mullite (HKT, France), orthoclase (Bancroft, Canada), pyrophyllite (Pyshminskoe deposit from Berezovskii, Rusia), and quartz (Barrueco Pardo, Salamanca, Spain) in order to compare them with the proportions of these minerals in our samples. It was not possible to get a standard for mixed-layer I-Sm.

Following the procedure described by Hillier (2003), various mixtures were prepared of the standards with corundum in known concentrations. These mixtures were then studied by XRD, and the pattern obtained in this case has a $3-50^{\circ} 2 \theta$ interval with a goniometer velocity of $0.1^{\circ} 2 \theta / \mathrm{s}$ and an integration time of $0.4 \mathrm{~s}$. Knowing the percentage of corundum and standard in each mixture and the characteristic reflections of each phase in the XRD patterns, the RIRcor of each standard was calculated using an $\mathrm{x}-\mathrm{y}$ graph. This graph (Fig. 1) shows the relation of the standard percentage with respect to the corundum (abscissa) versus the relation of the standard characteristic reflection intensity with respect to the corundum reflection (ordinates).

After determining the RIRcor for each standard, natural and fired samples were mixed with $10 \%$ corundum and analysed by XRD in order to quantify the weight percent (\%wt) of each mineral present. Working conditions in the diffractometer were the same as those used for the standards. The amount $(\mathrm{X})$ at each stage (i) in a mixed sample with corundum can be obtained with the formula: $\mathrm{Xi}=$ [Xcor/RIRcor $][\mathrm{I}$ (hkl)i/I(113)cor].

Xcor is the percentage of corundum mixed with the test sample, RIRcor the reflective power of each standard with respect to corundum, $\mathrm{I}(\mathrm{hkl})$ is the absolute intensity of the characteristic reflection of each mineral phase, and I(113)cor is the intensity of the (113) peak (2.08 $)$ of corundum. The results must be divided by 0.9 to obtain percentages (\%). The content of non-detected phases by XRD (e.g. amorphous or poor crystalline phases) and non-quantified phases (e.g. mixed-layer I$\mathrm{Sm}$ ) is obtained by default to add up to 100 ("Others" in Fig. 2). Reflections (hkl) used to determine the RIRcor of each mineral were $2.69 \AA$ for hematite, $10 \AA$ for illite, $7.17 \AA$ for kaolinite, $3.38 \AA$ for mullite, $3.24 \AA$ for orthoclase, $9.2 \AA$ for pyrophyllite, and $3.34 \AA$ for quartz.

\subsection{Optical and electron microscopy studies}

As the XRD results show the mineralogical changes were very similar in all three samples, sample CHECA-3B was chosen at random for the microscopy studies. First, thin sections of this sample (fired at different temperatures) were studied by transmitted light microscopy to identify the mineralogy and characterize its texture.

XRD results and transmitted light microscopy observations show that the sample fired at $900{ }^{\circ} \mathrm{C}$ had a similar texture and mineralogy to that fired at $800{ }^{\circ} \mathrm{C}$. Therefore, samples fired at $800,1000,1100,1200$, and $1300{ }^{\circ} \mathrm{C}$ were selected for study by electron microscopy. Thin sections of those samples were analysed by a Carl Zeiss Merlin field emission scanning electron microscope (FESEM) with an Oxford energy-dispersive X-ray (EDS) detector at the University of Zaragoza (Spain). Thin sections were previously coated with carbon.

Compositional images of the sample were obtained using two types of backscattered electron detectors: angular selective backscattered (AsB) and energy selective backscattered (EsB). To obtain chemical information, semi-quantitative analyses were acquired by energy-dispersive X-ray (EDS). This latter technique has a detection limit of $0.1 \%$. The accelerating voltage for AsB and EDS was $15 \mathrm{kV}$ with a beam current of $400 \mathrm{pA}$; for EsB, the accelerating voltage was $4 \mathrm{kV}$ with a beam current of $2.0 \mathrm{nA}$.

In order to establish the presence of a vitreous phase and its composition and relation with other mineral phases as mullite, sample CHECA-3B fired at $1000{ }^{\circ} \mathrm{C}, 1100^{\circ} \mathrm{C}$, and $1300{ }^{\circ} \mathrm{C}$ was analysed by Electron Microscope (TEM). The study was performed using a Jeol2000 FXII TEM equipped with an Oxford energy dispersive spectroscope (EDS) at the University of Zaragoza. The accelerating voltage was $200 \mathrm{kV}$ with a beam current of $20 \mathrm{~mA}$. For this study, a thin section (20 $\mu$ thick) was prepared and attached to the glass with Canada balsam, which melts on contact with heat. Copper rings ( $3 \mathrm{~mm}$ in external diameter and $1 \mathrm{~mm}$ in internal diameter) were attached in representative areas of the samples. Subsequently, the rings were cut off and ion milled with an ionic ION DUO MILL GATAN thinner, making them electron transparent.

\section{Results}

\section{1. $X$-ray diffraction $(X R D)$}

\subsubsection{RIRcor calculation}

The qualitative XRD study indicates that samples are formed by mixed-layer I-Sm, kaolinite, illite, pyrophyllite, hematite, mullite, quartz, and orthoclase. 

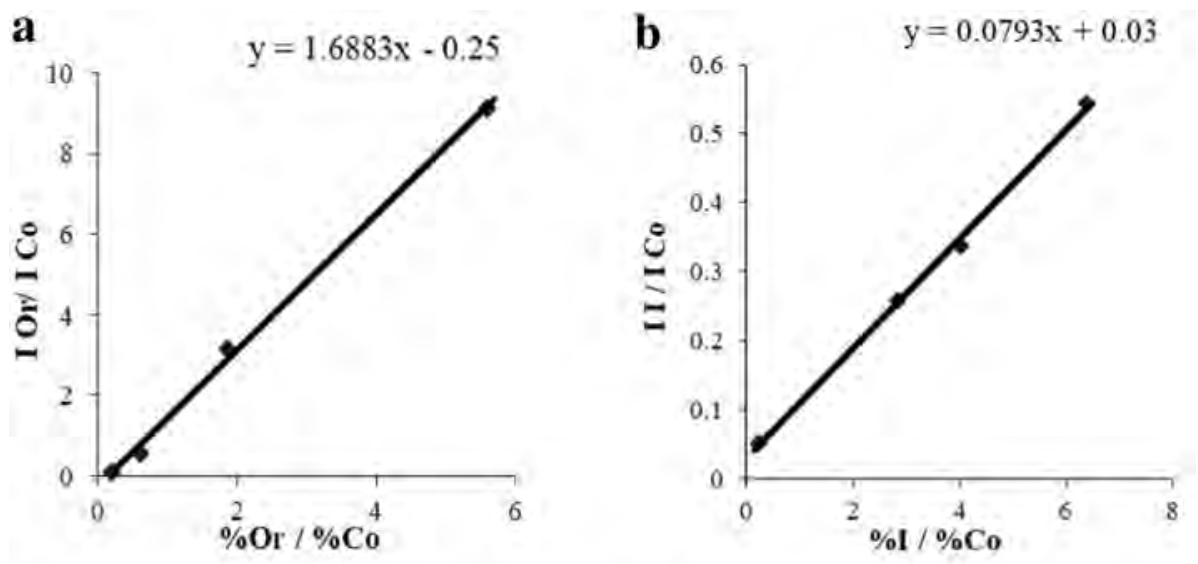

Fig. 1. RIRcor calculations for the standards: a) orthoclase, b) illite, c) pyrophyllite, d) kaolinite, e) hematite, f) mullite and g) quartz. The points on the graphs represent the mixtures of the standard with corundum. These points give a straight line and to determinate the RIRcor of the standards $\mathrm{x}$ is considered 1 .
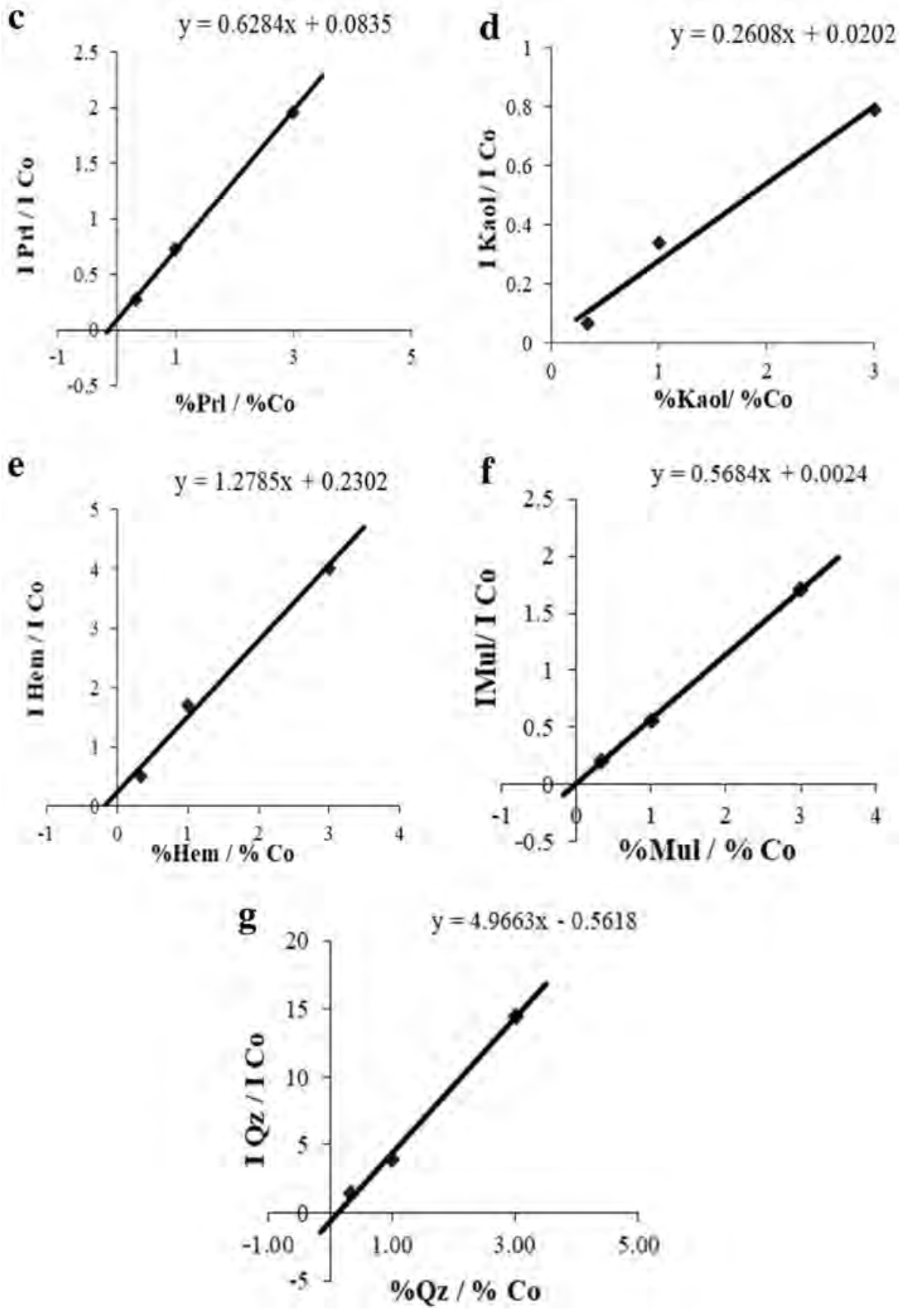

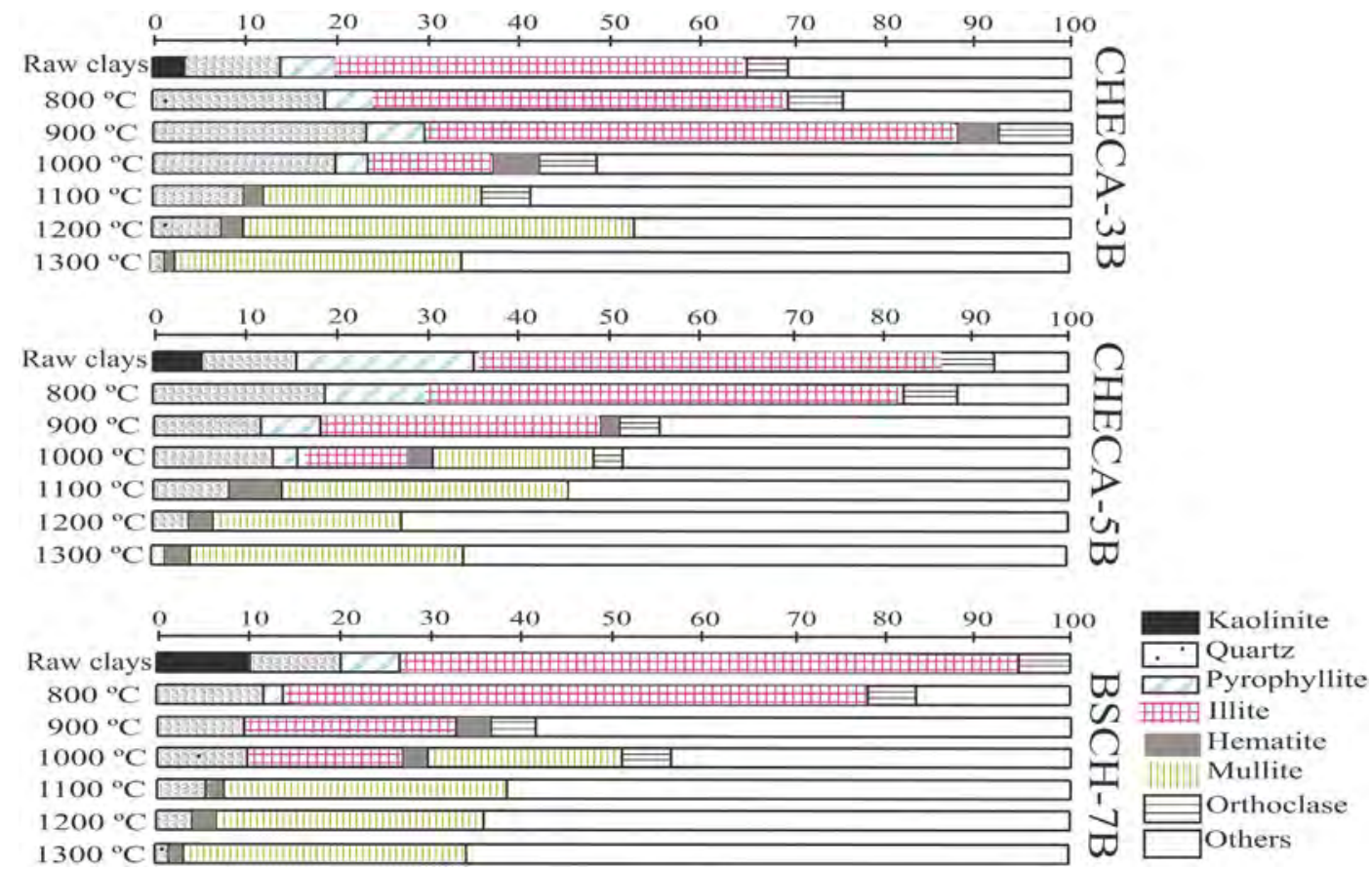

Fig. 2. Diagrams with the quantitative mineral composition of the analysed samples.

Table 1

RIRcor calculated for each standard.

\begin{tabular}{lc}
\hline Standard & RIRcor \\
\hline Orthoclase & 1.4330 \\
Illite & 0.1093 \\
Pyrophyllite & 0.7119 \\
Kaolinite & 0.2810 \\
Hematite & 1.5087 \\
Mullite & 0.5660 \\
Quartz & 4.4045 \\
\hline
\end{tabular}

Data on the percentage of the standard, that of corundum, and the intensities of the characteristic peaks of both phases in the mixture were used to calculate the RIRcor for the standards. The graphs plotting $\left(\mathrm{I}_{\text {mineral st }} / \mathrm{I}_{\text {cor }}\right)$ vs $\left(\%_{\text {mineral st }} / \%_{\text {cor }}\right)$ display straight lines (Fig. 1$)$. The lines obtained for each mineral and the RIRcor value (calculated considering $\mathrm{x}=1$ ) are shown in Table 1 .

\subsubsection{Qualitative analysis and mineral quantification}

Quantitative analyses of all the samples are shown in Fig. 2. A table with all the data is available in the supplementary material. As example, the XRD patterns of sample CHECA-3B are shown in Fig. 3.

The mineralogy of the three natural samples analysed is similar. They are formed principally by clays (55-85\%) and minor proportions of quartz (10-12\%) and orthoclase (4-5\%). Although illite is the most abundant clay (45-68\%), the samples have significant amounts of pyrophyllite (6-17\%), kaolinite (4-10\%), and low proportions of mixed-layer I-Sm. The section labelled "Others" includes the nonquantified phases, amorphous and poor crystalline phases (organic matter, titanium and/or iron oxides or oxyhydroxides) and the mixedlayer I-Sm that were not quantified. With the composition of natural samples known, the mineral variations produced by the temperature increase can be evaluated.

The XRD patterns (Fig. 3) show that, generally, at $800{ }^{\circ} \mathrm{C}$ kaolinite and mixed-layer I-Sm have disappeared. When the temperature increases, illite, pyrophyllite, and quartz start to destabilize and concurrently hematite (from $900{ }^{\circ} \mathrm{C}$ ) and mullite (between $1000{ }^{\circ} \mathrm{C}$ to $1100{ }^{\circ} \mathrm{C}$ depending on the sample) crystallize. At $1100{ }^{\circ} \mathrm{C}$, an increase in the diffractogram background is observed, indicating the presence of an amorphous/vitreous phase.

Illite contents decrease in all samples when the temperature increases (Fig. 2), and it is recognized up to $1000{ }^{\circ} \mathrm{C}$. The (001) reflection of this mineral decreases in intensity and increases in width with temperature. Pyrophyllite contents also decrease in all samples with an increase in temperature. Its percentage decreases in CHECA-3B and CHECA-5B, and it is absent in BSCH-7B. Quartz is present in all the raw and fired samples, with contents increasing progressively with temperature up to $1000{ }^{\circ} \mathrm{C}$ and then decreasing from $1100{ }^{\circ} \mathrm{C}$. Orthoclase is observed up to $1000-1100{ }^{\circ} \mathrm{C}$ depending on the sample and, when present, its contents are practically constant. Mullite is recognized from 1000 to $1100{ }^{\circ} \mathrm{C}$ and, when this mineral appears, clays, quartz, and orthoclase contents are significantly lower. At $1200{ }^{\circ} \mathrm{C}$ and $1300{ }^{\circ} \mathrm{C}$, mullite, hematite, and quartz are the only minerals recognizable. Quartz is the only mineral present in natural samples that remains at these high temperatures. Finally, the percentage allocated to other phases ("Other" in Fig. 2) increases from 1000 to $1100{ }^{\circ} \mathrm{C}$, which implies that it is mainly reflecting the vitreous phase content formed with the firing process. The presence of this vitreous phase is manifested in the XRD diffractograms, creating an increase in the pattern background (as shown in Fig. 3).

\subsection{Optical microscopy}

Thin sections of sample CHECA-3B observed by optical microscopy show the mineralogical and textural changes with the firing process (Fig. 4). At $800^{\circ} \mathrm{C}$ and $900{ }^{\circ} \mathrm{C}$, samples are formed by rock fragments from the milling of the natural sample before making the cylinders. These rock fragments are composed of quartz, pyrophyllite, muscovite, and a fine-grained matrix whose composition is similar to the rest of the sample. Phyllosilicates in the fragments maintain the orientation of the natural rock. In addition, opaque phases are differentiated, which probably correspond to $\mathrm{Fe}$ and/or Ti oxides (Fig. 4a). These textures are similar to those of sedimentary rocks. At $1000^{\circ} \mathrm{C}$, phyllosilicate orientation can also be appreciated inside the rock fragments (Fig. $4 \mathrm{~b}$ ). In these fragments, the same minerals are recognized as at $800{ }^{\circ} \mathrm{C}$ and $900{ }^{\circ} \mathrm{C}$, but their edges are beginning to be more diffuse, indicating the start of melting. The matrix presents the same mineralogy as at lower 


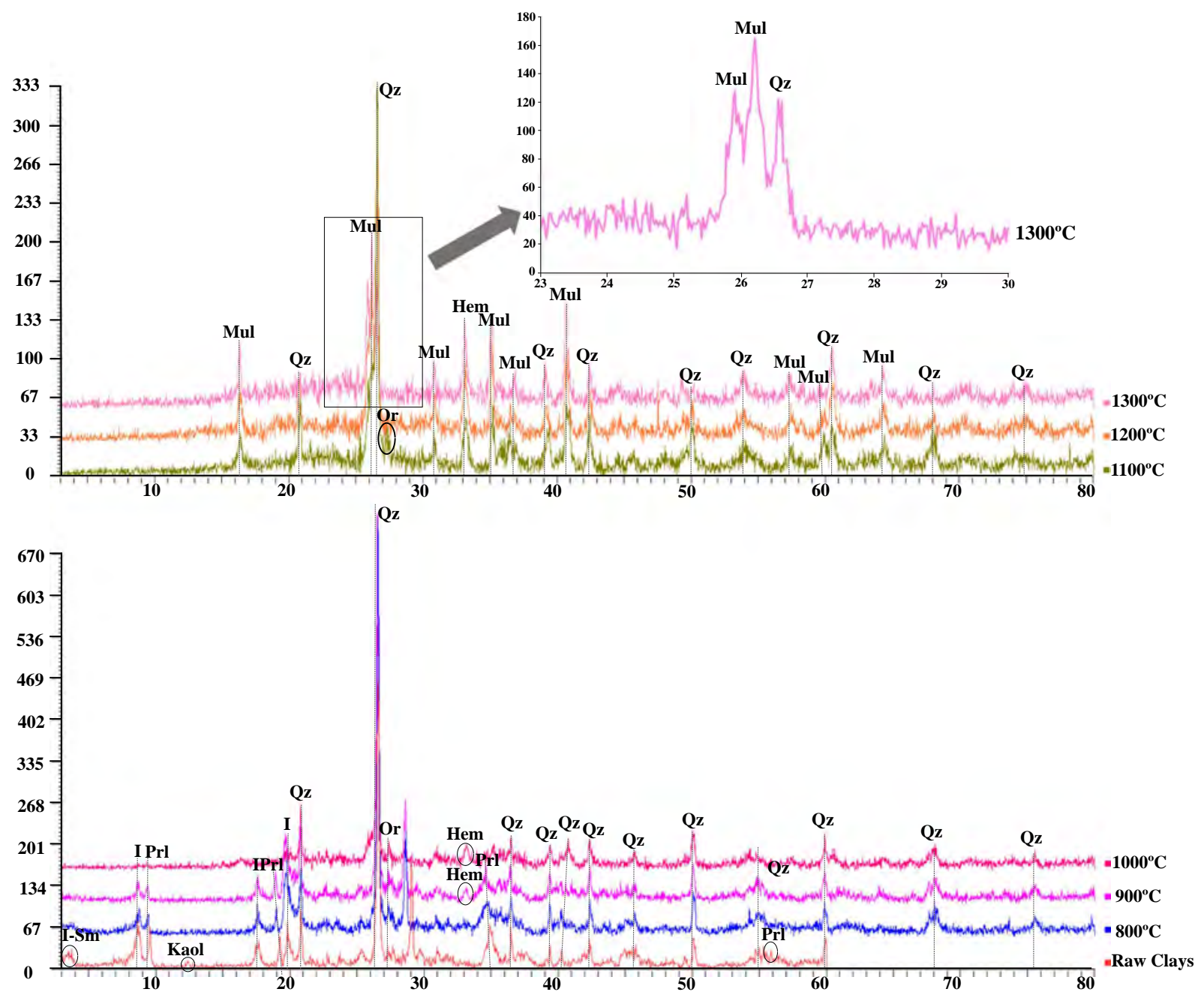

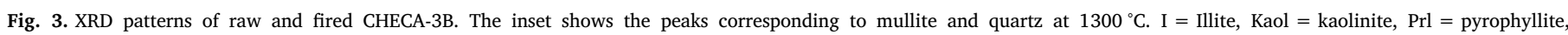
$\mathrm{Hem}=$ hematite, $\mathrm{Mul}=$ mullite, $\mathrm{Or}=$ orthoclase, $\mathrm{Qz}=$ quartz, $\mathrm{I}-\mathrm{Sm}=$ mixed-layer illite-smectite .

temperatures, but its behaviour is more isotropic and the opaque minerals are still distinguishable. At $1100^{\circ} \mathrm{C}$, rock fragments present incipient reaction edges (Fig. $4 \mathrm{c}$ ), the matrix is isotropic, and it contains quartz and opaque minerals. At $1200{ }^{\circ} \mathrm{C}$, the sample is practically isotropic and only clasts of quartz and opaque minerals can be made out. Finally, at $1300^{\circ} \mathrm{C}$, rock fragments are barely distinguishable and the matrix is practically isotropic, but opaque phases and quartz are observed in both of them (Fig. 4d).

\subsection{Field emission scanning electron microscopy (FESEM)}

Backscattered electron images (BSE) taken by FESEM from sample CHECA-3B show remarkable textural and compositional changes with the firing process. At $800{ }^{\circ} \mathrm{C}$ and $900{ }^{\circ} \mathrm{C}$, as in optical microscopy, the images show the presence of rock fragments with micron-sized clasts formed by quartz, muscovite, pyrophyllite, and $\mathrm{Fe}$ and $\mathrm{Ti}$ oxides (Fig. 5a). In these clasts, phyllosilicates show preferred orientation and, in some areas of the thin section, alteration edges. Illite, pyrophyllite, muscovite, chlorite, monazite, xenotime, anorthite, quartz, and Fe and Ti oxides are recognized in the matrix. These minerals come from the original rock. Phyllosilicates are practically intact in general, but in some areas they are replaced by Fe oxides. The oxides are variably grey, which indicates compositional variations possibly due to different degrees of hydration (e.g. Fe oxides and oxyhydroxides such as hematite and goethite).

At $1000{ }^{\circ} \mathrm{C}$, rock fragments with the same mineral phases identified at $800{ }^{\circ} \mathrm{C}$ and $900{ }^{\circ} \mathrm{C}$ are recognized (Fig. 5b). Pores are observed due to volatile loss produced as a result of firing processes. Firing causes the phyllosilicate sheets to separate, due to dihydroxylation (Evans and White, 1958; Guggenheim et al., 1987). At this temperature, micronsize Fe oxides seems to be more abundant than at lower temperatures, perhaps due to recrystallization with firing of amorphous or poorly crystalline Fe oxides or oxyhydroxides present in the natural sample. In the matrix, the same mineral phases noted at $800{ }^{\circ} \mathrm{C}$ and $900{ }^{\circ} \mathrm{C}$ are recognized. At $1100{ }^{\circ} \mathrm{C}$, rock fragments present reaction edges (Fig. $5 \mathrm{c}$ ), and the colour of the matrix is more homogeneous than a lower temperatures, suggesting a more homogenous chemical composition as the TEM analysis show in the corresponding section. Rock fragments have a similar texture to the matrix, where quartz clasts (which are fractured) are recognized, and occasionally orthoclase, pyrophyllite, and $\mathrm{Fe}$ and $\mathrm{Ti}$ oxides. The matrix, observed as isotropic under optical microscopy, is fairly homogeneous in composition, and the number of phases decreases with temperature. These amorphous areas are mainly formed by $\mathrm{Al}$ and $\mathrm{Si}$ with minor $\mathrm{K}$. Accessory REE-rich aluminium phosphates have been observed as relicts of the original rock. At this temperature, mullite is recognized, with an acicular/prismatic morphology and nanometric length (Fig. 5d).

At $1200{ }^{\circ} \mathrm{C}$, rock fragments are barely distinguished and are practically in continuity with the amorphous matrix, whose composition is very homogeneous (Fig. 6a). Quartz is quite fractured and shows reaction edges (Fig. 6b). Other minerals observed are mullite, Fe and Ti oxides, and occasionally zircon and xenotime that probably were 

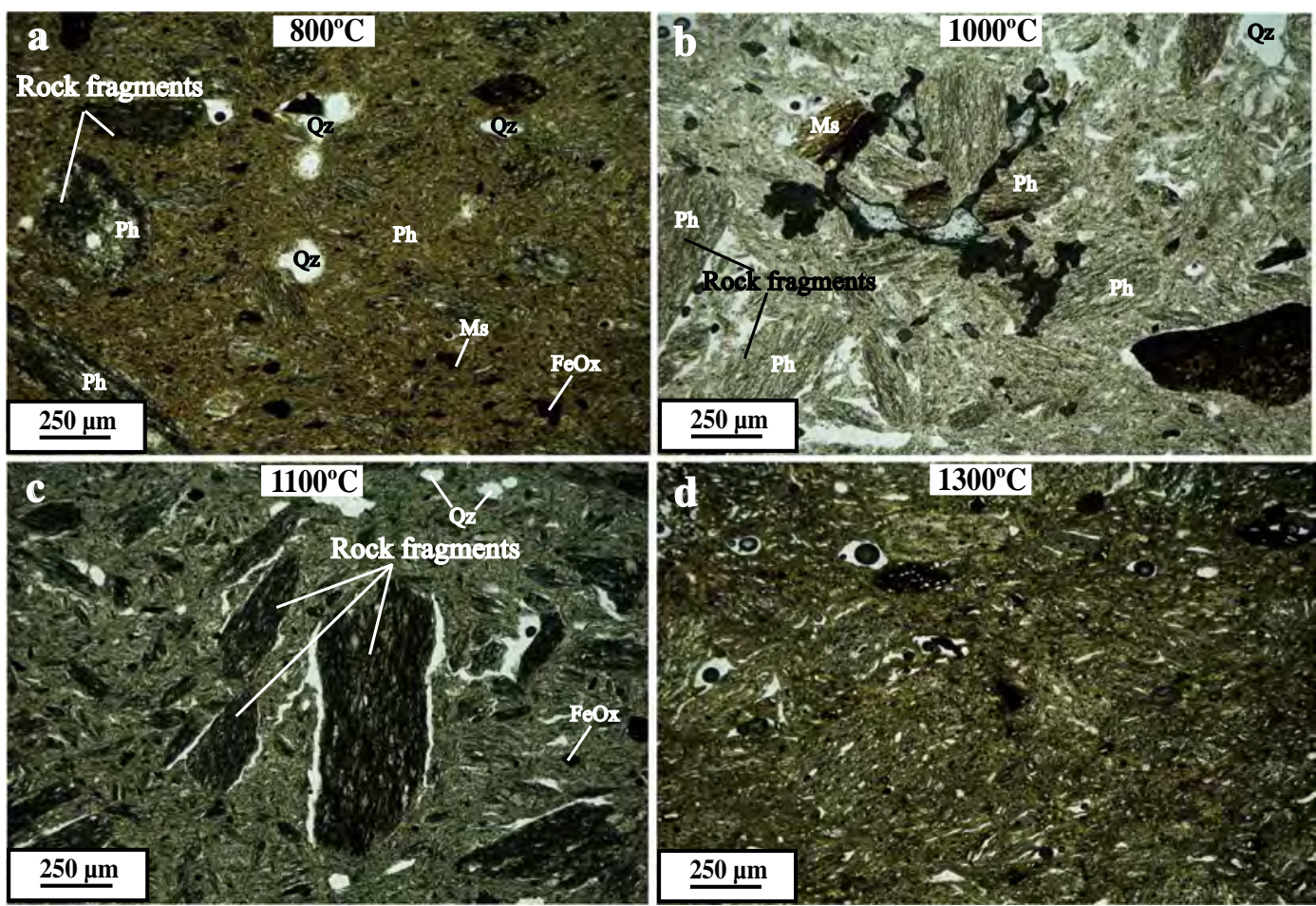

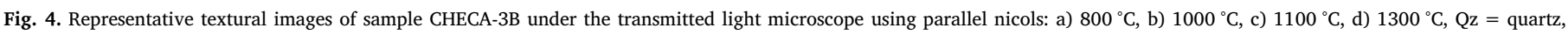
$\mathrm{Ms}=$ muscovite, $\mathrm{Fe} \mathrm{Ox}=\mathrm{Fe}$ oxides, $\mathrm{Ph}=$ phyllosilicates.

present in the rock clay. Mullite has the same morphology as at $1100{ }^{\circ} \mathrm{C}$, but is more abundant in the $1200{ }^{\circ} \mathrm{C}$ sample. Finally, at $1300{ }^{\circ} \mathrm{C}$, the sample has very homogeneous grey contrasts (Fig. $6 \mathrm{c}$ ) indicating that the composition is more uniform. The mineralogy mainly consists of mullite, Fe and Ti oxides, and the homogeneous phase that forms the vitreous matrix. The amount and size of mullite crystals increase, they are heterometric, and randomly oriented (Fig. 6d).

\subsection{Transmission electron microscopy (TEM)}

TEM images (Fig. 7) reveal mullite crystals with acicular morphology and random orientation in a matrix. Furthermore, the lack of electron diffraction patterns implies the matrix is amorphous/vitreous.

Analysed mullites show variable and non-stoichiometric compositions (Table 2, Fig. 8). Fig. 8a, b shows that there is a clear correlation in the $\mathrm{Si} / \mathrm{Al}$ content of the mullites with the increase of the firing temperature. Mullites crystallized at $1000^{\circ} \mathrm{C}$ and $1100{ }^{\circ} \mathrm{C}$ have higher $\mathrm{Si}$ and lower $\mathrm{Al}$ content that the theoretical mullite (Fig. 8a). In the case of mullites crystallized at $1300{ }^{\circ} \mathrm{C}$ the $\mathrm{Si} / \mathrm{Al}$ ratio decreases and their compositions are closer to the theoretical one. The $\mathrm{Al}$ contents range from 17.48 to $39.61 \%$, Si from 11.48 to $29.58 \%$, Fe from 0.15 to $2.43 \%$,
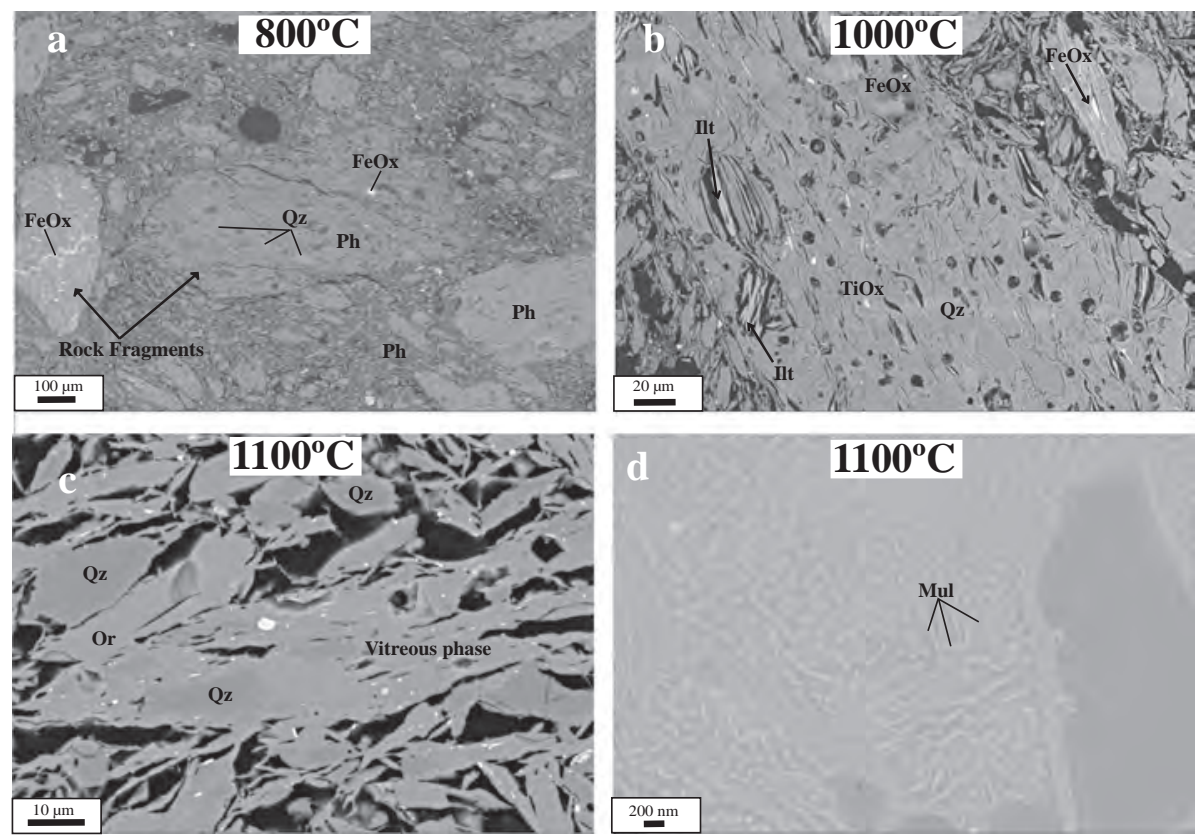

Fig. 5. Backscattered electron images (FESEM) of sample CHECA-3B: a) sample fired at $800{ }^{\circ} \mathrm{C}$ showing similar texture than that of the sample without firing, b) sample fired at $1000{ }^{\circ} \mathrm{C}$, showing phyllosilicate sheets separated, possibly due to dehydroxylation process, c) sample fired at $1100{ }^{\circ} \mathrm{C}$ that show fragments of quartz with reaction edges and immersed in a vitreous phase, d) sample fired at $1100{ }^{\circ} \mathrm{C}$ that displays nanometer-acicular crystals of mullite with random orientation immersed in a vitreous phase. $\mathrm{Qz}=$ quartz,$\quad \mathrm{I}=$ illite,$\quad \mathrm{Fe} \quad \mathrm{Ox}=\mathrm{Fe} \quad$ oxides, $\mathrm{Ph}=$ phyllosilicates, $\mathrm{Ti} \mathrm{Ox}=\mathrm{Ti}$ oxides, $\mathrm{Or}=$ Orthoclase. 


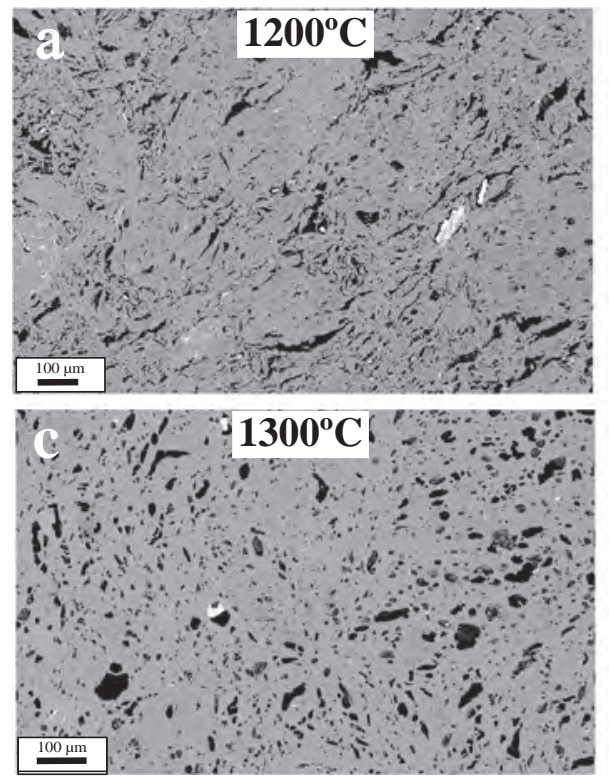

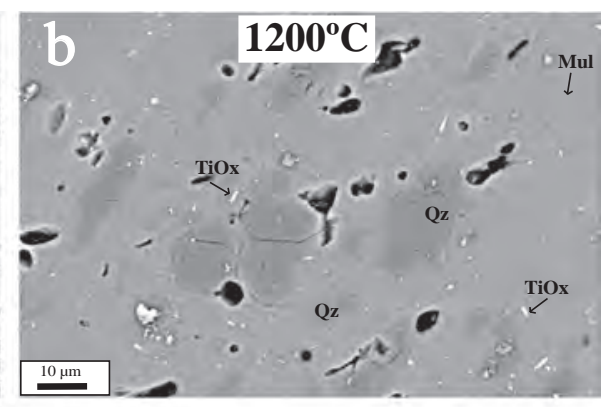

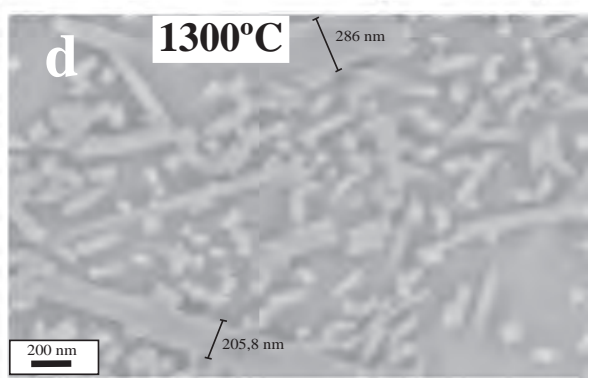

Fig. 6. Backscattered electron images (FESEM of sample CHECA-3B: a) sample fired at $1200{ }^{\circ} \mathrm{C}$ showing the texture characteristics of an advanced vitrification process, b) sample fired at $1200{ }^{\circ} \mathrm{C}$ that displays fractured quartz with more developed reaction edges and immersed in a vitreous phase with nanometer mullite, c) sample fired at $1300{ }^{\circ} \mathrm{C}$ that shows the texture characteristics of an intense vitrification process, d) nanometer sized acicular crystals of mullite with random orientation immersed in a vitreous matrix. $\mathrm{Qz}=$ quartz, $\mathrm{Ti} \mathrm{Ox}=\mathrm{Ti}$ oxides, $\mathrm{Mul}=$ mullite. and $\mathrm{Ti}$ from 0 to $1 \% \mathrm{Al}, \mathrm{Fe}$ and $\mathrm{Ti}$ contents increase with the firing temperature while the $\mathrm{Si}$ decreases, as Fig. 8a, c show, indicating that these elements substitute $\mathrm{Si}$ in the mullite structure. The $(\mathrm{Al}+\mathrm{Fe}$ $+\mathrm{Ti}) / \mathrm{Si}$ ratio increases from $0.89\left(1000{ }^{\circ} \mathrm{C}\right)$ to $1.10\left(1100{ }^{\circ} \mathrm{C}\right)$ and to $2.01\left(1300^{\circ}\right)$, closer to the $\mathrm{Al} / \mathrm{Si}$ ratio of the theoretical mullite $(2.88)$.

The vitreous phase has in general a silicon-aluminium rich composition (Table 2, Fig. 8d) with $\mathrm{Si} / \mathrm{Al}$ higher than 1 ; it also contains minor proportions of $\mathrm{Fe}, \mathrm{K}, \mathrm{Ti}, \mathrm{Na}, \mathrm{Mg}$, and $\mathrm{Ca}$ that reflect the mineral and chemical composition of the raw rock.

The crystal size of mullite (thickness) increases with temperature (Fig. 7), from 2 to $3 \mathrm{~nm}$ thick at $1000{ }^{\circ} \mathrm{C}$, to $20-35 \mathrm{~nm}$ thick at $1100{ }^{\circ} \mathrm{C}$, and $40-70 \mathrm{~nm}$ thick at $1300{ }^{\circ} \mathrm{C}$. These changes indicate a decrease in the number of crystalline defects in the mullite.

\section{Discussion}

\subsection{Mineral and textural transformations during the firing process}

\subsubsection{Mineral transformations}

The total clay contents decrease when the temperature increases during the firing process, indicating that they are less stable phases than quartz and orthoclase. Analysing the stability of each of the clays reveals that kaolinite is one of the least stable phases since it is not present at $800{ }^{\circ} \mathrm{C}$. In a natural process such as the transition between diagenesis and very low-grade metamorphism (anchizone), kaolinite is destabilized and replaced by other phases such as illite or pyrophyllite depending on the chemistry of the rock in question (Merriman and Peacor, 1999), suggesting that kaolinite is not stable at temperatures above $200{ }^{\circ} \mathrm{C}$ in natural environments. In ceramic processes, some authors have reported the presence of amorphous metakaolinite from 500 to $1000{ }^{\circ} \mathrm{C}$ being this phase the precursor of mullite (Chakraborty and Ghosh, 1978; Chen et al., 2000; Meng et al., 2016).

Mixed-layer I-Sm is also highly unstable with temperature since, like kaolinite, it is not present at $800{ }^{\circ} \mathrm{C}$. In natural environments, these phases destabilize during late diagenesis and can be replaced by illite (Merriman and Peacor, 1999).

In the samples studied, pyrophyllite is more stable than kaolinite and mixed-layer I-Sm. Although its contents decrease with an increase in firing temperature, it remains until temperatures of $900-1000{ }^{\circ} \mathrm{C}$. However, it is likely that, at temperatures of $450-550{ }^{\circ} \mathrm{C}$, its structure has undergone dehydroxylation and collapsed, resembling an illite-type structure (Evans and White, 1958; Guggenheim et al., 1987). This produces an increase in the width of the reflections in the X-ray patterns. Experimental data indicate that pyrophyllite crystallizes in environments with quartz and kaolinite at $240-460{ }^{\circ} \mathrm{C}$ and $2.1 \mathrm{kbar}$ pressure, suggesting that, in natural environments, it is formed under very low-grade metamorphism (Frey, 1987) or in hydrothermal alterations of that temperature range (Inoue, 1995). This explains the greater stability of pyrophyllite compared to kaolinite and mixed-layer $\mathrm{I}$-Sm during the ceramic process. The fact that it remains until $1000^{\circ} \mathrm{C}$ during the firing process is probably due to the speed of the temperature change. In ceramic firing, the rate is very fast, but as the kinetics of the reactions are slow, the mineral transformations are incomplete. In a similar way, Riccardi et al. (1999) describe that the reactions between mineral grains present in the raw clay and the matrix are dominated by disequilibrium conditions and characterized by the presence of different reacting sub-systems. This fact makes the stability range of this mineral broader during firing than in natural environments.

The predominant mineral in natural samples is illite and it remains the most abundant until $1000{ }^{\circ} \mathrm{C}$. Therefore, it is much more stable in the firing process than kaolinite and mixed-layer I-Sm, and it has a similar stability to pyrophyllite. In fired samples, the illite content decreases from $900{ }^{\circ} \mathrm{C}$ up, but from $450{ }^{\circ} \mathrm{C}$ it will have undergone dehydroxylation processes like pyrophyllite, which is reflected in the morphology of its peaks in XRD patterns. It can be observed that the reflection peak of illite at 9.9-10 $\AA$ is broader in fired samples than in natural ones. The typical metamorphic rocks of greenschist facies (corresponding to temperatures around $350{ }^{\circ} \mathrm{C}$ ) do not contain illite, being formed by muscovite and chlorite (Merriman and Peacor, 1999). Like pyrophyllite, illite remains stable at higher temperatures in firing ceramics than in natural environments, probably due as well to the high speed of the firing process.

Orthoclase proportions are very low in natural samples and do not vary with temperature until $1000^{\circ} \mathrm{C}$, at which point, this phase begins to destabilize and disappears. Quartz remains from the natural sample to $1300{ }^{\circ} \mathrm{C}$, although its contents begin to decrease from $1000{ }^{\circ} \mathrm{C}$.

During ceramic firing, the destabilization of phases in natural samples favours the formation of hematite, mullite, and the vitreous phase. Hematite crystallizes at $900{ }^{\circ} \mathrm{C}$ from oxides and/or oxyhydroxides. Mullite is a scarce mineral in nature; however, it is common in artificial products such as porcelain, refractories with high alumina content, etc. Some works reported mullite crystallization associated to the calcination of clays by spontaneous coal combustion (Alastuey et al., 1993) and with pyrometamorphic environments (Markl, 2005; 


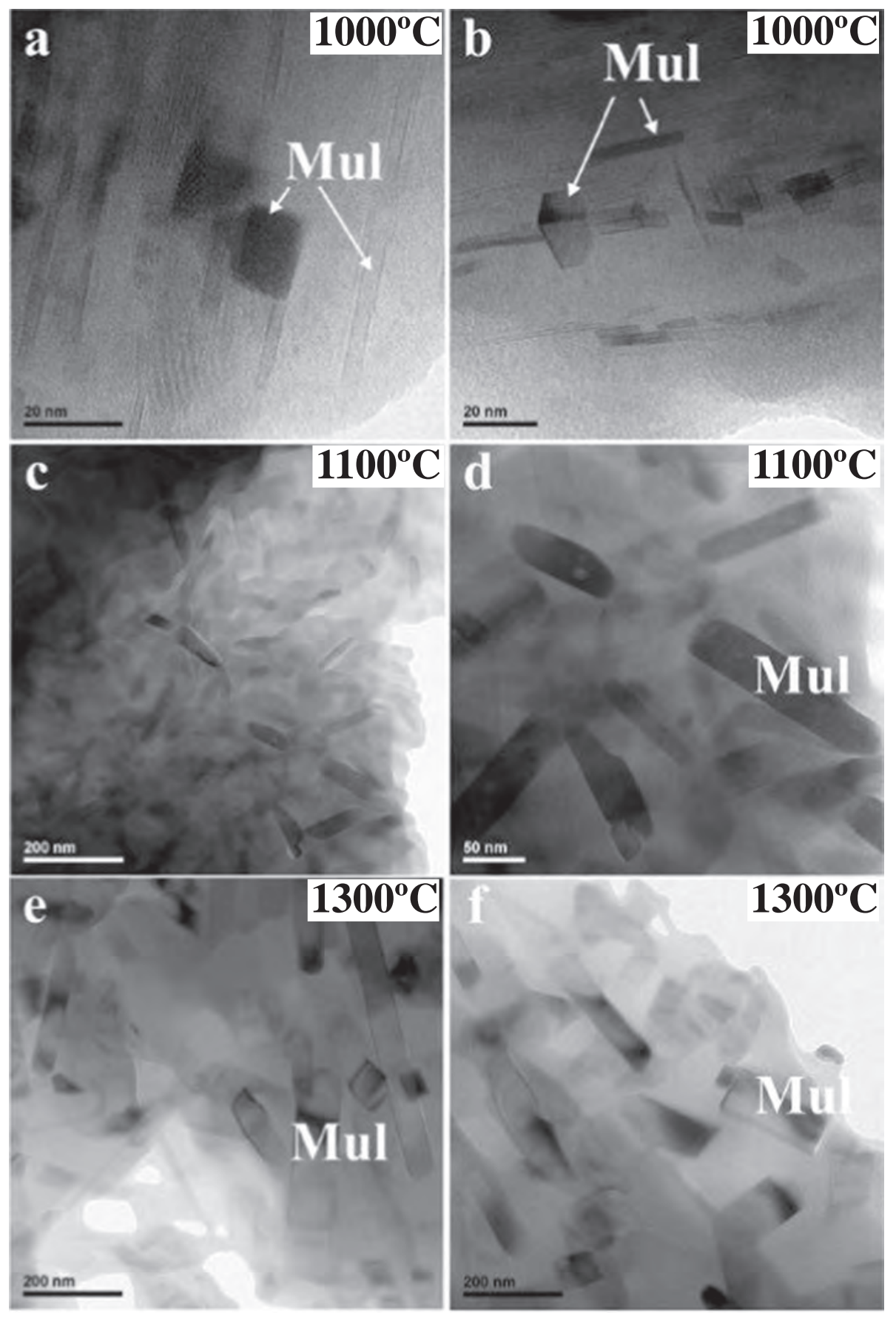

Fig. 7. Representative TEM images corresponding to sample CHECA-3B fired at $1100^{\circ}, 1100{ }^{\circ} \mathrm{C}$ and $1300{ }^{\circ} \mathrm{C}$ that show acicular mullite crystals, with random orientation in a vitreous phase. The mullite increases its crystal thickness with the increase of the temperature. Mul $=$ mullite.

Sokol et al., 1998). The vitreous phase begins to form from $1000{ }^{\circ} \mathrm{C}$, and its contents increase in samples as the firing temperature rises.

Although the mineral transformations with temperature from the three samples studied are similar, there are minor differences in the stability ranges of some minerals. These disparities may be due to the particle size of the minerals in each of the samples since the smaller sizes are more reactive during firing.

\subsubsection{Textural changes}

The study by optical microscopy and FESEM indicates that the overall texture of samples changes when the temperature increases. At low firing temperatures $\left(800-900^{\circ} \mathrm{C}\right)$, sample texture is very similar to natural samples, and rock fragments are recognized in an anisotropic matrix. The phyllosilicates in these rock fragments are practically intact and retain their orientation as in the rocks studied by Bauluz and Subías (2010).
As the temperature increases $\left(1000-1100{ }^{\circ} \mathrm{C}\right)$, the rock fragments and the matrix develop pores due to volatile loss due to dehydroxylation during firing. Dehydroxylation is the structural transformation that leads to the loss of $\mathrm{OH}$ groups in the structure or water loss in the crystalline material through a reduction process that can be achieved through firing (Palacios et al., 2012). Under optical microscopy, the rock fragments have reaction edges and are more isotropic than samples fired at lower temperatures. The vitrification process can also be seen in the matrix and results in greater homogeneity in the FESEM as well. The phyllosilicate sheets separate due to dehydroxylation during firing.

At $1200{ }^{\circ} \mathrm{C}$, the rock fragments are practically indistinguishable and are in continuity with the matrix, which is very homogeneous in composition and isotropic under the optical microscope, which indicates an increase in the vitreous content. At this temperature, abundant recognizable quartz clasts contain fractures due to firing dynamics 
Table 2

TEM analyses (\%wt) of vitreous phase and mullite crystals and electron microprobe analyses (\%wt) of natural mullite crystals from the literature.

Composition of mullite

\begin{tabular}{|c|c|c|c|c|c|c|c|c|c|}
\hline \multirow[t]{16}{*}{$1000^{\circ} \mathrm{C}$} & $\mathrm{Na}$ & $\mathrm{Mg}$ & $\mathrm{Al}$ & $\mathrm{Si}$ & K & $\mathrm{Ca}$ & $\mathrm{Ti}$ & $\mathrm{Fe}$ & $\mathrm{O}$ \\
\hline & 0.08 & 0.62 & 22.20 & 25.39 & 0.65 & 0.20 & 0.00 & 1.28 & 49.58 \\
\hline & 0.00 & 0.11 & 19.06 & 27.90 & 1.19 & 0.54 & 0.00 & 1.57 & 49.63 \\
\hline & 0.37 & 3.38 & 25.65 & 22.89 & 0.04 & 0.02 & 0.00 & 1.07 & 46.58 \\
\hline & 0.40 & 0.36 & 19.49 & 27.49 & 0.80 & 0.00 & 0.28 & 1.41 & 49.77 \\
\hline & 0.24 & 0.86 & 22.79 & 24.52 & 0.30 & 0.12 & 0.31 & 1.32 & 49.54 \\
\hline & 0.05 & 0.52 & 17.55 & 29.55 & 0.61 & 0.23 & 0.27 & 0.93 & 50.29 \\
\hline & 0.16 & 0.14 & 17.48 & 26.30 & 0.30 & 0.08 & 0.41 & 1.00 & 54.13 \\
\hline & 0.15 & 0.30 & 23.01 & 23.42 & 0.31 & 0.00 & 0.00 & 0.71 & 52.10 \\
\hline & 0.23 & 0.07 & 19.17 & 25.43 & 0.34 & 0.02 & 0.05 & 1.51 & 53.18 \\
\hline & 0.28 & 0.00 & 25.02 & 21.20 & 0.39 & 0.22 & 0.34 & 1.26 & 51.29 \\
\hline & 0.51 & 0.11 & 24.28 & 22.60 & 0.25 & 0.00 & 0.09 & 1.43 & 50.73 \\
\hline & 0.60 & 0.08 & 20.04 & 24.58 & 0.31 & 0.25 & 0.25 & 1.03 & 52.86 \\
\hline & 0.03 & 0.40 & 20.59 & 22.99 & 0.16 & 0.25 & 0.00 & 0.70 & 54.88 \\
\hline & 0.35 & 0.19 & 20.98 & 23.10 & 0.44 & 0.09 & 0.00 & 0.50 & 54.35 \\
\hline & 0.00 & 0.06 & 18.57 & 27.69 & 1.00 & 0.00 & 0.00 & 0.96 & 51.72 \\
\hline \multirow[t]{21}{*}{$1100^{\circ} \mathrm{C}$} & $\mathrm{Na}$ & $\mathrm{Mg}$ & $\mathrm{Al}$ & $\mathrm{Si}$ & $\mathrm{K}$ & $\mathrm{Ca}$ & $\mathrm{Ti}$ & $\mathrm{Fe}$ & $\mathrm{O}$ \\
\hline & 0.31 & 0.69 & 26.33 & 21.26 & 0.64 & 0.09 & 0.10 & 1.66 & 48.92 \\
\hline & 0.06 & 0.27 & 22.85 & 24.97 & 0.61 & 0.27 & 0.19 & 1.15 & 49.63 \\
\hline & 0.03 & 0.21 & 23.25 & 24.47 & 0.54 & 0.21 & 0.23 & 1.55 & 49.51 \\
\hline & 0.00 & 0.34 & 25.75 & 22.73 & 0.20 & 0.00 & 0.22 & 1.19 & 49.57 \\
\hline & 0.36 & 0.06 & 27.25 & 21.09 & 0.37 & 0.12 & 0.09 & 1.60 & 49.06 \\
\hline & 0.44 & 0.43 & 22.44 & 25.28 & 0.21 & 0.07 & 0.13 & 1.28 & 49.72 \\
\hline & 0.10 & 0.00 & 23.88 & 23.25 & 0.54 & 0.16 & 0.32 & 1.00 & 50.75 \\
\hline & 0.12 & 0.04 & 18.05 & 26.50 & 0.44 & 0.12 & 0.10 & 0.29 & 54.34 \\
\hline & 0.00 & 0.09 & 20.78 & 26.88 & 0.33 & 0.15 & 0.00 & 0.58 & 51.19 \\
\hline & 0.00 & 0.26 & 18.86 & 26.63 & 0.32 & 0.41 & 0.00 & 0.15 & 53.37 \\
\hline & 0.19 & 0.10 & 18.66 & 23.77 & 0.50 & 0.06 & 0.06 & 0.60 & 56.06 \\
\hline & 0.00 & 0.39 & 18.03 & 27.40 & 0.34 & 0.03 & 0.18 & 0.63 & 53.00 \\
\hline & 0.13 & 0.00 & 32.28 & 14.10 & 0.26 & 0.00 & 0.15 & 0.73 & 52.35 \\
\hline & 0.23 & 0.23 & 24.91 & 19.31 & 0.37 & 0.34 & 0.11 & 0.65 & 53.85 \\
\hline & 0.00 & 0.11 & 27.57 & 17.60 & 0.10 & 0.07 & 0.15 & 0.21 & 54.19 \\
\hline & 0.13 & 0.31 & 25.87 & 20.71 & 0.42 & 0.14 & 0.00 & 0.56 & 51.86 \\
\hline & 0.00 & 0.19 & 17.92 & 27.05 & 0.63 & 0.27 & 0.06 & 0.62 & 53.26 \\
\hline & 0.93 & 0.54 & 24.10 & 19.92 & 1.31 & 0.02 & 0.79 & 1.19 & 51.20 \\
\hline & 0.00 & 0.00 & 24.45 & 16.67 & 0.32 & 0.09 & 0.17 & 1.81 & 56.49 \\
\hline & 0.25 & 0.00 & 26.18 & 17.49 & 1.15 & 0.36 & 0.29 & 2.08 & 52.20 \\
\hline \multirow[t]{11}{*}{$1300{ }^{\circ} \mathrm{C}$} & $\mathrm{Na}$ & $\mathrm{Mg}$ & $\mathrm{Al}$ & $\mathrm{Si}$ & $\mathrm{K}$ & $\mathrm{Ca}$ & $\mathrm{Ti}$ & $\mathrm{Fe}$ & $\mathrm{O}$ \\
\hline & 0.00 & 0.00 & 30.34 & 18.76 & 0.20 & 0.00 & 0.21 & 1.51 & 48.98 \\
\hline & 0.00 & 0.00 & 26.72 & 21.96 & 0.22 & 0.00 & 0.23 & 1.46 & 49.41 \\
\hline & 0.00 & 0.00 & 35.51 & 13.95 & 0.07 & 0.00 & 0.22 & 2.04 & 48.21 \\
\hline & 0.00 & 0.87 & 39.61 & 11.48 & 0.00 & 0.00 & 0.09 & 2.43 & 45.52 \\
\hline & 0.33 & 0.00 & 29.70 & 14.78 & 0.01 & 0.00 & 0.00 & 1.58 & 53.60 \\
\hline & 0.44 & 0.00 & 27.10 & 19.85 & 0.05 & 0.31 & 1.00 & 1.39 & 49.86 \\
\hline & 0.45 & 0.16 & 25.03 & 22.07 & 0.42 & 0.02 & 0.00 & 0.71 & 51.14 \\
\hline & 0.38 & 0.00 & 36.57 & 12.26 & 0.17 & 0.09 & 0.26 & 2.12 & 48.15 \\
\hline & 0.00 & 0.05 & 28.02 & 17.42 & 0.37 & 0.00 & 0.00 & 1.90 & 52.24 \\
\hline & 0.00 & 0.00 & 34.94 & 13.09 & 0.05 & 0.00 & 0.27 & 1.41 & 50.24 \\
\hline \multirow[t]{2}{*}{ Markl (2005) } & $\mathrm{Na}$ & $\mathrm{Mg}$ & $\mathrm{Al}$ & $\mathrm{Si}$ & $\mathrm{K}$ & $\mathrm{Ca}$ & $\mathrm{Ti}$ & $\mathrm{Fe}$ & $\mathrm{O}$ \\
\hline & 0.15 & 0.04 & 35.85 & 13.48 & 0.01 & 0.01 & 0.29 & 1.02 & 49.15 \\
\hline \multirow{3}{*}{$\begin{array}{r}\text { Sokol et al. } \\
\text { (1998) }\end{array}$} & $\mathrm{Na}$ & $\mathrm{Mg}$ & $\mathrm{Al}$ & $\mathrm{Si}$ & $\mathrm{Cr}$ & Mn & $\mathrm{Ti}$ & $\mathrm{Fe}$ & $\mathrm{O}$ \\
\hline & - & 0.10 & 37.90 & 10.80 & 0.00 & 0.00 & 0.10 & 3.90 & 47.00 \\
\hline & - & 0.20 & 32.80 & 15.80 & 0.00 & 0.00 & 0.20 & 3.20 & 47.80 \\
\hline
\end{tabular}

Composition of the vitreous phase

\begin{tabular}{llllllllll}
\hline $1000{ }^{\circ} \mathrm{C}$ & $\mathrm{Na}$ & $\mathrm{Mg}$ & $\mathrm{Al}$ & $\mathrm{Si}$ & $\mathrm{K}$ & $\mathrm{Ca}$ & $\mathrm{Ti}$ & $\mathrm{Fe}$ & $\mathrm{O}$ \\
& 0.00 & 0.60 & 13.46 & 30.01 & 2.05 & 0.48 & 0.88 & 3.63 & 48.89 \\
& 1.54 & 0.65 & 20.91 & 23.27 & 2.50 & 1.43 & 0.26 & 1.65 & 49.30 \\
& 0.33 & 0.74 & 12.32 & 30.48 & 1.69 & 1.61 & 1.75 & 2.05 & 49.33 \\
$1100{ }^{\circ} \mathrm{C}$ & 1.82 & 0.38 & 11.93 & 30.99 & 3.10 & 0.41 & 0.28 & 2.56 & 50.32 \\
& $\mathrm{Na}$ & $\mathrm{Mg}$ & $\mathrm{Al}$ & $\mathrm{Si}$ & $\mathrm{K}$ & $\mathrm{Ca}$ & $\mathrm{Ti}$ & $\mathrm{Fe}$ & $\mathrm{O}$ \\
& 0.31 & 0.18 & 19.70 & 27.76 & 0.93 & 0.23 & 0.00 & 0.97 & 50.23 \\
& 0.77 & 0.94 & 23.04 & 23.20 & 0.83 & 0.57 & 0.00 & 1.91 & 49.55 \\
$1300{ }^{\circ} \mathrm{C}$ & 0.74 & 0.46 & 22.63 & 22.87 & 1.35 & 0.41 & 0.69 & 2.49 & 49.05 \\
& $\mathrm{Na}$ & $\mathrm{Mg}$ & $\mathrm{Al}$ & $\mathrm{Si}$ & $\mathrm{K}$ & $\mathrm{Ca}$ & $\mathrm{Ti}$ & $\mathrm{Fe}$ & $\mathrm{O}$ \\
& - & - & 23.22 & 24.24 & 1.17 & - & 0.67 & 1.36 & 49.34 \\
& - & - & 13.09 & 32.20 & 2.13 & - & 1.53 & 0.99 & 50.07
\end{tabular}

and subsequent cooling. It generates a polymorphic transformation from low quartz to high quartz and back to low quartz. Quartz frequently has alteration edges with an intermediate composition between that of quartz and that of the vitreous matrix (Fig. 6b), probably the fluxing action of the interlayer cations (K) of illite inhibits formation of cristobalite as Wattanasiriwech et al. (2009) and Aras (2002) describe during the vitrification of illitic clays. At $1300{ }^{\circ} \mathrm{C}$, the texture and the composition are very homogeneous and only mullite, quartz, and hematite are recognized in the vitreous phase.

\subsubsection{Genesis and composition of the vitreous phase and mullite}

Mullite crystallizes in these samples from $1000{ }^{\circ} \mathrm{C}$, forming acicular crystals distributed with variable orientations in the fired samples and whose thickness increases with temperature up to $40-70 \mathrm{~nm}$. Analyses of natural mullite using electron microprobe have been reported by Markl (2005) and Sokol et al. (1998). Markl (2005) gives the composition of mullite formed in xenolithes in contact with pyrometamorphic interaction (Table 2, Fig. 8b) and Sokol et al. (1998) describe mullites formed in pyrometamorphic rocks associated with naturally burned coal (Table 2. Fig. 8b).

The composition reported by these authors indicates that the natural mullite contains higher proportions of $\mathrm{Al}$ than $\mathrm{Si}$ (Fig. 8b) and minor proportions of $\mathrm{Fe}$ and $\mathrm{Ti}$, which fits with the theoretical composition of mullite (38 wt $\% \mathrm{Al}, 13.18 \mathrm{wt} \% \mathrm{Si}$ and $48.82 \mathrm{wt} \% \mathrm{O}$ ). However, the mullite composition in this study (Table 2) differs from the theoretical one because it has much lower $\mathrm{Al}$ content and is not stoichiometric (Fig. 8a, b). This is probably a consequence of the temperature of crystallization of the natural described mullites and the fact that the length of time of the thermal geological process is much longer than a ceramic firing.

Nevertheless, the composition of the mullites crystallized at $1300{ }^{\circ} \mathrm{C}$ during the ceramic process is closer to theoretical mullite than those of 1000 and $1100{ }^{\circ} \mathrm{C}$. The increase in crystal size and the changes in composition with firing indicate that the number of crystalline defects in the mullite decreases with increased temperature.

The $\mathrm{Fe}$ and $\mathrm{Ti}$ in the mullite structure possibly derive from the hematite and some Ti oxides whose destabilization is contemporaneous with mullite crystallization, as XRD data show (Fig. 2). The fact that the mullite analysed is not stoichiometric at $1000-1100{ }^{\circ} \mathrm{C}$ compared to the theoretical one and to the natural mullites may be due to the dynamics of the firing process that produce incomplete mineral reactions. Fielitz et al. (2006) propose a reaction model for the diffusion-controlled mullite formation. Probably the aluminium diffusion would be lower at $1000-1100{ }^{\circ} \mathrm{C}$ than at $1300{ }^{\circ} \mathrm{C}$. This is supported by the fact that at the highest temperature the analysed mullites have compositions closer to the theoretical one.

The formation of the vitreous phase in the fired samples is deduced from $1000{ }^{\circ} \mathrm{C}$ and its amount increases progressively up to $1300{ }^{\circ} \mathrm{C}$. The textural study reveals the existence of this vitreous phase and mullite crystals immersed in it, which confirms the hypothesis that the mullite crystallizes from this vitreous phase (Lee et al., 2008; Marinoni et al., 2013). According to TEM analyses (Table 2), this vitreous phase has a $\mathrm{Si}$ - and $\mathrm{Al}$-rich composition with minor proportions of $\mathrm{Fe}, \mathrm{Ti}, \mathrm{K}, \mathrm{Na}, \mathrm{Mg}$, and $\mathrm{Ca}$ and presents significant compositional variations depending on the area and sample analysed (Table 2). These variations are due to the fact that the vitreous phase formed from the melting of minerals (mostly silicates) that were heterogeneously distributed in the initial samples. There are differences in composition among the vitreous phase and mullite crystals, as Fig. $8 \mathrm{a}$, d show.

\subsection{Clays and firing process}

The clays of this study react with firing differently to other clays 

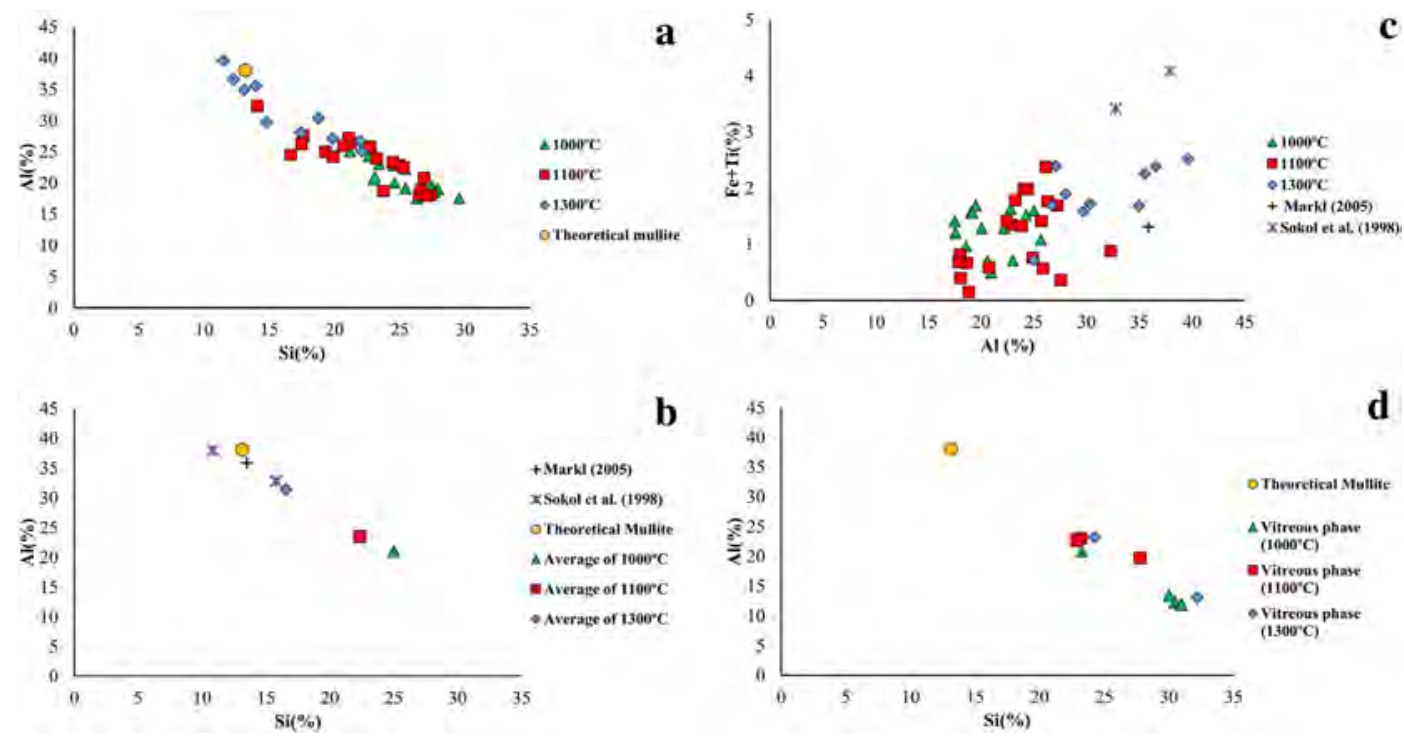

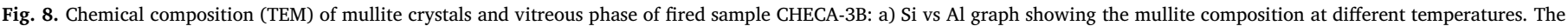

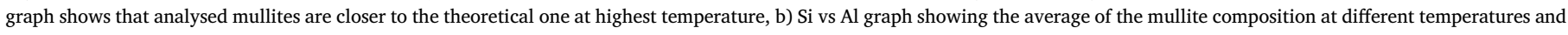

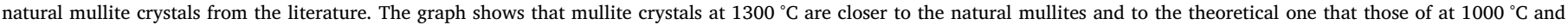

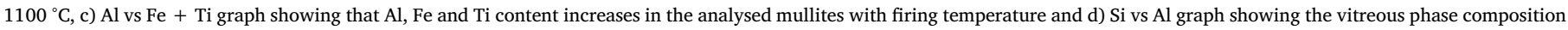
at different temperatures. The graph shows that its composition present significant variations and differences with the mullite crystals.

used in the ceramic industry. Bauluz et al. (2004) studied the mineral transformations during the firing process of carbonate- and illite-rich clays, showing that illite and carbonate-rich clays are very reactive and the formation of vitreous phase starts at $800^{\circ} \mathrm{C}$. However, the vitreous phase in the current samples form from $1000^{\circ} \mathrm{C}$ which is probably due to the significant contents in aluminium-rich clays (kaolinite and pyrophyllite) and low contents in illite in the studied clays. On the other hand, the textural and mineralogical characteristics of these samples indicate that, during the firing process, equilibrium is not reached, leaving incomplete mineral reactions.

This absence of chemical and mineralogical equilibrium is evident in the coexistence during the entire firing process of phases from the raw sample with phases generated during the firing process, and the formation of mullite with anomalous compositions.

The ceramic process consists of mineral transformations at high temperature and low pressure and is influenced not only by the mineralogical composition of the raw material and its granulometry but also by the temperature, the firing speed, and the atmospheric conditions of the kiln (Maggetti, 1982). If we compare the firing process with a natural process such as contact metamorphism, the biggest difference is that the temperature increase is very fast and the firing time very short. Therefore, during the ceramic process, mineral transformations are incomplete, the chemical system shows an absence of equilibrium, and the formed phases are not stoichiometric.

\section{Conclusions}

The study by optical microscopy, XRD, FESEM, and TEM of aluminium-rich shale samples fired between $800{ }^{\circ} \mathrm{C}$ and $1300{ }^{\circ} \mathrm{C}$ reflects significant mineralogical and textural changes during the firing process.

These changes include the loss of organic matter, kaolinite and mixed-layer I-Sm, the destabilization of orthoclase, dehydroxylation, and the subsequent fusion of illite and pyrophyllite and, to a lesser degree, of quartz, which is partially replaced by vitreous material. Hematite is formed from $900{ }^{\circ} \mathrm{C}$, and mullite formation and the vitrification process start at $1000{ }^{\circ} \mathrm{C}$. The texture of the rock clearly changes at $1000^{\circ} \mathrm{C}$ with the melting of most of the initial phases, the formation of a vitreous phase, the crystallization of mullite and hematite, and the presence of quartz. With firing, the mineralogy is simplified and homogenized.

From $1000{ }^{\circ} \mathrm{C}$ mullite crystallizes from the $\mathrm{Si}$ - and Al-rich vitreous phase. The mullite composition is not stoichiometric but as temperature increases its composition approaches to the theoretical one and that of natural mullites analysed in the literature. On the other hand, as the firing process advances $\mathrm{Si}$ is partially replaced by $\mathrm{Al}, \mathrm{Fe}$ and $\mathrm{Ti}$ in the structure. Furthermore mullite crystal thickness increases with temperature up to $70 \mathrm{~nm}$.

The differences observed in the stability of some minerals in the different samples may be due to their particle size. In addition, the incomplete chemical and mineralogical equilibrium caused by the short duration of the firing process allows the coexistence of natural sample phases with those generated during the firing phases as well as the formation of non-stoichiometric mullite.

Finally, it can be concluded that the results obtained in this work provide useful information regarding the firing process of aluminium clays that can be used in the manufacture of ceramic products.

\section{Acknowledgements}

This research was funded by the Spanish Ministry of Education and Science (CGL2013-46169-C2-1-P), and the Gobierno de Aragón and the European Social Fund ("Grupos Consolidados"). Authors would like to acknowledge the use of the Servicio General de Apoyo a la Investigación-SAI, University of Zaragoza. They would also like to thank C. Gallego and M.A. Laguna for their advice during the FESEM and TEM sessions. Our appreciation also goes out to the reviewers Dra. Nathalie Fagel and an anonymous reviewer to help us to improve the manuscript, and to Christine Laurin for editing the English.

\section{Appendix A. Supplementary data}

Supplementary data to this article can be found online at https:// doi.org/10.1016/j.clay.2017.11.025.

\section{References}

Alastuey, A., Bastida, J., Fernández Turiel, J.L., Querol, X., Signes, M., 1993. Mineralogía de las arcillas calcinadas de la base de la Fm. Escucha en el área de Foz-Calanda. Cuadernos de Geología Ibérica. 17, 171-184. Change of phase composition in 
kaolinite- and illite-rich clay-based ceramic bodies. Appl. Clay Sci. 24, 257-269.

Aras, A., 2002. The change of phase composition in kaolinite- and illite-rich clay-based ceramic bodies. Appl. Clay Sci. 24, 257-269.

Bauluz, B., Subías, I., 2010. Coexistence of pyrophyllite, I-S, R1 and NH4 +-rich illite in Silurian black shales (sierra de Albarracín, NE Spain): metamorphic vs. hydrothermal origin. Clay Miner. 45, 383-392.

Bauluz, B., Mayayo, M.J., Yuste, A., Fernandez-Nieto, C., Gonzalez, J.M., 2004. TEM study of mineral transformations in fired carbonated clays: relevance to brick making. Clay Miner. 39, 333-344.

Chakraborty, A.K., Ghosh, D.K., 1978. Reexamination of the kaolinite-to-mullite reaction series. Journal of the American of ceramic. Society 61, 170-173.

Chen, C.Y., Lan, G.S., Tuan, W.H., 2000. Microstructural evolution of mullite during the sintering of kaolin powder compacts. Ceram. Int. 26, 715-720.

Cultrone, G., Rodriguez-Navarro, C., Sebastian, E., Cazalla, O., De la Torre, M.J., 2001. Carbonate and silicate phase reactions during ceramic firing. Eur. J. Mineral. 13, 621-634.

Evans, J.L., White, J., 1958. Further studies of the thermal decomposition of clays. Transactions of the British ceramic. Society 57, 298.

Fielitz, P., Borchardt, G., Schmücker, M., Schneider, H., 2006. A diffusion-controlled mullite formation reaction model being based on tracer diffusivity data of aluminium, silicon and oxygen. Phil. Mag. 87, 11-127.

Frey, M. (Ed.), 1987. Low Temperature Metamorphism. Blackie, Glasgow.

Guggenheim, S., Chang, Y., Koster van Groos, A.F., 1987. Muscovite dehydroxylation: high-temperature studies. Am. Mineral. 72, 537-550.

Gutiérrez-Marco, J.C., Storch, P., 1998. Graptolite biostratigraphy of the lower Silurian (Llandovery) shelf deposits of the western Iberian cordillera, Spain. Geol. Mag. 135, 71-92.

Hillier, S., 2003. Quantitative analysis of clay and other minerals in sandstones by X-ray powder diffraction (XRPD). Int. Assoc. Sedimentol. Spec. Publ. 34, 213-251.

Inoue, A., 1995. Formation of clay minerals in hydrothermal environments. In: Velde, B.
(Ed.), Origin in Mineralogy of Clays. Springer, Berlin, pp. 268-329.

Lee, W.E., Souza, G.P., McConville, C.J., Tarvornpanich, T., Iqbal, Y., 2008, Mullite formation in clays and clay-derived vitreous ceramics. J. Eur. Ceram. Soc. 28, 465-471.

Maggetti, M., 1982. Phase analysis and its significance for technology and origin. In: Olin, J.S. (Ed.), Archeological Ceramics. Smithsonian Institution Press, Boston, pp. 121-133.

Marinoni, N., D'Alessio, D., Diella, V., Pavese, A., Francescon, F., 2013. Effects of sodalime-silica waste glass son mullite formation kinetics and micro-structures development in vitreous ceramics. J. Environ. Manag. 124, 100-107.

Markl, G., 2005. Mullite-corundum-spinel-cordierite-plagioclase xenoliths in the Skaergaard marginal border group: multi-stage interaction between metasediments and basaltic magma. Contrib. Mineral. Petrol. 149, 196-215.

Martín, J.D., 2007. Using XPowder: A Software Package for Powder X-Ray Diffraction Analysis. pp. 105. (Retrieved 18 April 2007 from). www.xpowder.com.

Meng, Y., Gong, G., Wei, D., Xie, Y., 2016. In situ high temperature X-ray diffraction study on high strength aluminous porcelain insulator with the $\mathrm{Al}_{2} \mathrm{O}_{3}-\mathrm{SiO}_{2}-\mathrm{K}_{2} \mathrm{O}-\mathrm{Na}_{2} \mathrm{O}$ system. Appl. Clay Sci. 132-133, 760-767.

Merriman, R.J., Peacor, D.R., 1999. Very low-grade metapelites: mineralogy, microfabrics and measuring reaction progress. In: Frey, M., Robinson, D. (Eds.), Low-Grade Metamorphism. Blackwell Science, Oxford, pp. 10-60.

Palacios, P.R., De Los Santos Valladares, L., Bustamante, A., González, J.C., 2012. Estudio de la deshidroxilación en el óxido férrico hidratado denominado limolita. Revista de la Sociedad Química del Perú 78, 198-207.

Riccardi, M.P., Messiga, B., Duminuco, P., 1999. An approach to the dynamics of clay firing. Appl. Clay Sci. 15, 393-409.

Sokol, E., Volkova, N., Lepezin, G., 1998. Mineralogy of pyrometamorphic rocks associated with naturally burned coal-bearing spoil-heaps of the Chelyabinsk coal basin, Russia. Eur. J. Mineral. 10, 1003-1014.

Wattanasiriwech, D., Srijan, K., Wattanasiriwech, S., 2009. Vitrification of illitic clay from Malaysia. Appl. Clay Sci. 43, 57-62. 